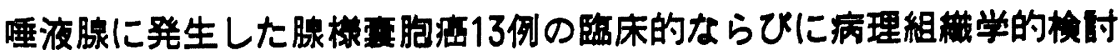

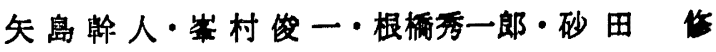 \\ 田村 稔・合科密治・武田進・小谷朗 \\ 山崎 正*
}

\section{Clinicopathological studies on 13 cases of adenoid cystic carcinoma originating from the salivary gland}

\author{
Mikito Yajima - Toshikazu Minemura - Shuichiro Nebashi \\ Osamu Sunada - Minotu Tamura - Kenji Kurashina \\ Susumu TAKEDA - Akira Kotani - Tadashi Yamazaxi*
}

\begin{abstract}
Thirteen cases of adenoid cystic carcinoma originating from the salivary gland treated in our Department from 1966 to 1987 were studied clinically and pathologically, in an attempt to clarify its correlation between clinical stage, histological grade and prognosis. Both sexes were almost equally represented ( 7 male and 6 female) and the patients ranged from 39 to 79 years old. The primary sites of the tumors were 7 submandibular gland, 4 palate, 1 parotid gland and 1 buccal mucosa. The cases were classified according to the TNM classifcation (UICC 1987) and the histological grading (Szanto et al. 1984).

The results were defined as follows:

1) It was suggested that the histological grade and the clinical behavior should be correlated to each other. The prognosis of patients with the tumor of Grade III and Stage IV was most poor. All of these patients died of distant metastasis.

2) In addition to histological grading, primary site, perineural invasion and bone invasion should be considered as other important factors. These findings appeared to be useful in predicting the prognosis.

3) Patients with finding of positive surgical margin had the tendency that local recurrence was generated. Clinically, however, complete removal of the primary tumor was difficult, especially in the minor salivary gland. The planned combination of surgery and irradiation, adjuvant immunochemotherapy and multidisciplinary therapy should be considered.
\end{abstract}

Key words: adenoid cystic carcinoma, salivary gland, clinicopathological finding

信州大学医学部菌科口腔外科学教室

（主任：小谷 朗教授）

* 小諸厚生総合病院料科口腔外科

（主任：山䗁 正医長）

Department of Dentistry and Oral Surgery, Shinshu University School of Medicine (Chief:

Prof. Akira Kotani)

* Department of Dentistry and Oral Surgery, Komoro Kousei General Hospital (Chief: Tadashi Yamazaki)

受付日：昭和63年 3 月 22 日
藉 言

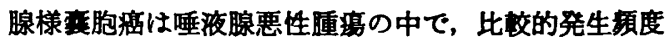
が高く，特に顎下腺，口蓋に好発するとされている．組 樴学的には典型的な篩状粠造を示すはかに，管状型，充 実型もみられそれれらの組織型のなかでは一般と充実型 が最る高悪性所見を示し，予後不良であるといわれてい $3^{1)}$.

今回，著者らは過去22年間に当科を受診した喠液腺原 
紊 1 対像症倒

\begin{tabular}{|c|c|c|c|c|c|c|c|}
\hline No. & 年䶕 & 性 & 原器部位 & 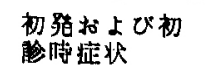 & 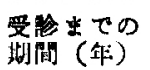 & 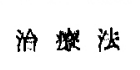 & 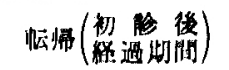 \\
\hline 1 & 53 & 女 & 耳下䭰 & 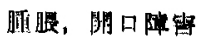 & 15 & $R+C$ : & ) (11か月) \\
\hline $2^{*}$ & 79 & 女 & 敫下䅨 & 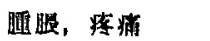 & 15 & $\mathrm{R}+\mathrm{c}:$ & J)(1作 6 加) \\
\hline $3^{*}$ & 65 & 男 & 䫑下腺 & 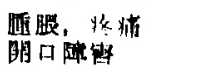 & 8 & $s$ & I) (4价) \\
\hline 4 & 51 & 女 & 顆下㴵 & 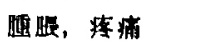 & 3 & $S+R$ & 1) ( 2 作 5 只 $)$ \\
\hline 5 & 63 & 男 & 影下腺 & 随煺，瘙痛 & 5 & $S$ & Ao (6 年) \\
\hline $6^{*}$ & 62 & 男 & 额下腺 & 随限 & 10 & $s$ & Ao ( 5 年 5 名) \\
\hline $7^{*}$ & 70 & 女 & 頻下腺 & 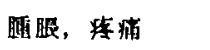 & 17 & $S$ & Do ( 1 作 2 力月) \\
\hline 8 & 39 & 男 & 影下腺 & 通脹 & 0.5 & $\mathrm{~S}+\mathrm{R}+\mathrm{C}$ & Ao $(8$ 力 $)$ \\
\hline 9 & 77 & 男 & 煩粘搭 & 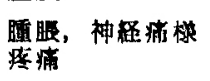 & 1.5 & $\mathrm{~S}$ & Ao（6年10加月） \\
\hline 10 & 47 & 男 & ～蓝 & 近琏，饶凊 & 0.5 & $\mathrm{~S}+\mathrm{C}$ & Ao（16年） \\
\hline 11 & 59 & 女 & 口蓝 & 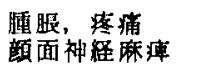 & 1.5 & $S+C$ & Do ( 3 年 10 か月) \\
\hline 12 & 72 & 男 & 口 䔲 & 睡腿 & 2 & $\mathrm{~S}$ & Ao ( 2 年 4 名月) \\
\hline 13 & 41 & 女 & 口 蓋 & 隀脹 & 1 & $\mathrm{~S}$ & Ao（17年） \\
\hline
\end{tabular}

* : 二次症例

$\mathbf{S}$ : 外科搌法

Ao : 無店生存

Do: 他病死

R：放射線㙩洗

C : 化学療法

Dc: 原病死

発腺様蕫胞癌13例について，臨床的，病理組籍学的所見 と治療経過，予後との関連を中心に検討を行い，若干の 知見を得たので報告する。

\section{対 象 症 例}

対象は，1966年から1987年までの22年間に当科で，病 理組織学的に腺様毫胞癌と診断され治療を行った 13 例 で,一次症例 9 例，二次症例 4 例であった。 なお，同期 間に当科を受診した唾液腺㣫湯患者は56例（良性腫場27 例, 悪性隀湯29例) であり，腺様襄胞癌は全体の $23 \%$ で, 多形性腺腫24例（43\%）に次いで多く，悪性腫瘍中では $45 \%$ と最す多かった。

\section{結果}

\section{1) 性, 年龄 (表 1)}

性別は男性 7 例，女性 6 例でほぼ同数であった。初診 時年齢は39〜79藏（平均60歳）に分布し，50〜70藏代が 10例 $(80 \%)$ を占め，中高年踰層に多くみられた。

2) 原発部位 (表 1)

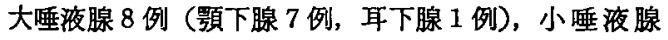
5 例（口蓋 4 例，頼部 I 例）で，顎下腺と口蓋が全体の $85 \%$ を占めた。

3）初発および初診時症状, 受診までの期間（表 1)

初発症状は全例腫脹, 膨隆であり，初診時に疼痛を併 発した症例か～ 8 例と多く, 頼部に発生した I 例は神経痛

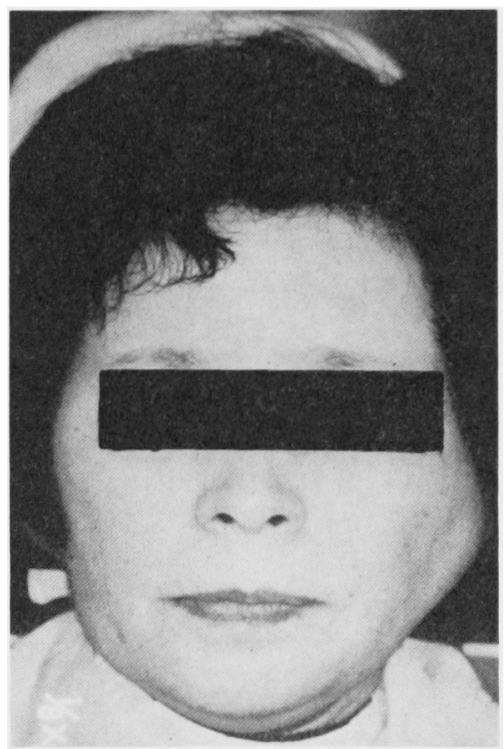

写卉 $1 \mathbf{a}$ 初診時顔貌（应例 1)

初発より15年経過した左耳下腺原発例

様疼痛を呈していた，また，口蓋原発の1 例に顔面神経 麻瘦がみられ，耳下腺，顎下腺原発各 1 例では，開口障 害を生していた，謴㴻形成を伴っていたものは 2 例あ り, 顎下腺，口蓋原発の各1例であった，症状発生から 受診までの期間は，最高 17 年 (平均 6 年) と長く， 5 年 
以上程過していたものが 6 例みられた。

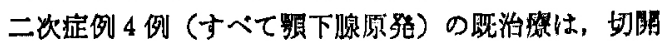
1 例，摘出術 3 例（放射線治澄併用 2 例）て，一次治橉 䅂了後 $2 \sim 7$ 年後に坶発をきたし，当科を受胗した。

\section{4) 臑濡の大巻さ}

球径が取小 $1.8 \mathrm{~cm} \sim$ 取大 $7.0 \mathrm{~cm}$ までみられ, $2.0 \mathrm{~cm}$ 以下 1 例, $2.1 \sim 4.0 \mathrm{~cm} 4$ 例, $4.1 \sim 6.0 \mathrm{~cm} 5$ 侧，6.1 $\mathrm{cm}$ 以上 3 例であった，最大は耳.下腺例の $7.0 \times 6.0 \times 2.0$ $\mathrm{cm}$ 大で (写充 $1 \mathrm{a}), 4.1 \mathrm{~cm}$ 以上のるのが半数以上を 占めた。

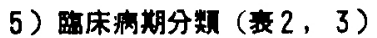

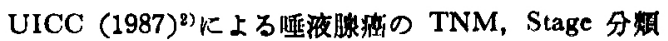
を適用した。 その結果，Stage I 1 例 (T1aNOM0：1 例), Stage II 4 例 (T2bNOM0: 2 例, T3aNOM0: 2 例), Stage III 4 例 (T3bNOM0: 2 例, T3bN1M0: 1 例, T2bN1M0：1例)，Stage IV 4 例 (T4bNOM0: 1 例, T4bN1M1：2 例, T2bN2M0：1例）であった。 この5ち二次症例 4 例についてみると，Stage II，II各 1 例, Stage $\mathrm{N} 2$ 例と一次症例に比校し進展した症例が

表 2 TNM 分類

\begin{tabular}{c|c|c|c|c|c|c}
\hline & T1a & T2b & T3a & T3b & T4b & \\
\hline N0 & 1 & 2 & 2 & 2 & 1 & 8 \\
N1 & & 1 & & 1 & $2^{*}$ & 4 \\
N2 & & 1 & & & & 1 \\
\hline & 1 & 4 & 2 & 3 & 3 & 13 \\
\hline
\end{tabular}

*: M1 (肺転移)

二次症例 $(4$ 例) を含む。
多かった．原発策の亜分類では局所進展を恓める $\mathrm{Tb}$ 例 が10例を占め，顆骨への漫泗を示したるのが多数みられ

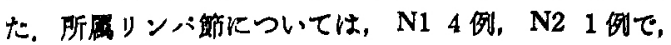

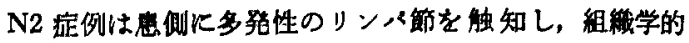
にも枟移を根めた。道雨枟移については，T4bN1の2

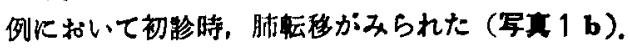

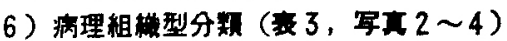

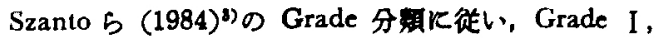
II 各 5 例, Cirarlr III 3 例であった。

\section{7) 治法法（表 1)}

一次症例，二次症例とむに外科撩法が主体で，手街不

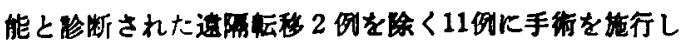

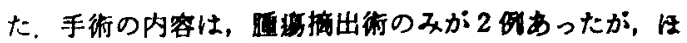

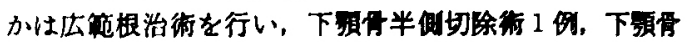

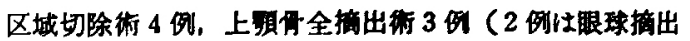

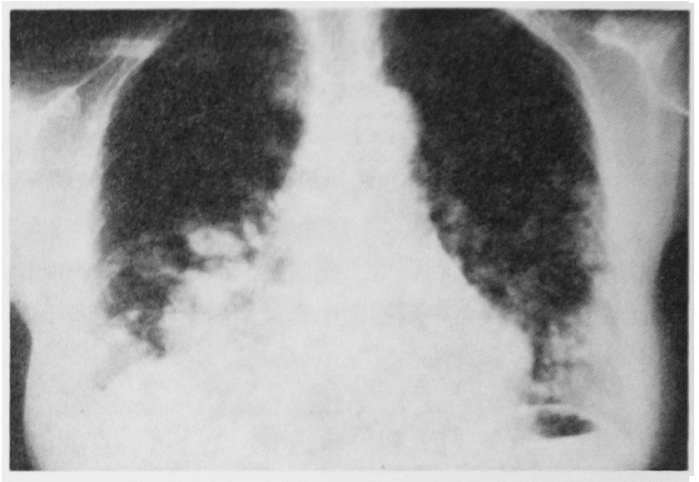

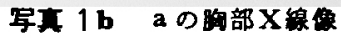

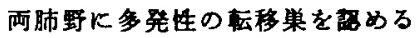

表 3 Grade 別臨床・病理所見

\begin{tabular}{|c|c|c|c|c|c|c|c|c|c|}
\hline Grade & No. & 原発部位 & TNM (Stage) & $\mathbf{N}$ & B & 切除断站 & 所再発 & 遠滆転移 & 転州 \\
\hline \multirow{5}{*}{ I } & 5 & 䫑下腺 & T2bN0M0 (II) & - & + & - & - & - & Ao \\
\hline & $6^{*}$ & 額下腺 & T3aN0M0 (II) & - & - & - & - & - & Ao \\
\hline & $7^{*}$ & 靧下腺 & T4bNOM0 (IV) & - & + & - & - & - & Do \\
\hline & 8 & 顎下腺 & T3aN0M0 (II) & - & - & + & + & - & Ao \\
\hline & 10 & 口蓋 & T2bN0M0 (II) & + & + & + & + & - & Ao \\
\hline \multirow{5}{*}{ II } & $2^{*}$ & 影下腺 & T4bN1M1 (IV) & - & + & ， & - & + (肺) & De \\
\hline & $3^{*}$ & 䅡下腺 & $\mathrm{T} 2 \mathrm{bN} 1 \mathrm{M} 0$ (II) & - & + & + & + & - & $\mathrm{Dc}$ \\
\hline & 9 & 頓粘膜 & T3bN1M0 (II) & + & + & - & - & - & Ao \\
\hline & 11 & 口＼cjkstart蓋 & T3bN0M0 (II) & + & + & + & + & + (媨) & De \\
\hline & 13 & 口蓋 & TlaNoM0 (I) & - & - & - & - & - & Ao \\
\hline \multirow{3}{*}{ III } & 1 & 耳下腺 & T4bN1M1 (IV) & - & + & 1 & - & + (肺) & Dc \\
\hline & 4 & 靧下腺 & T2bN2M0 (IV) & + & + & + & + & + (肺) & $\mathrm{Dc}$ \\
\hline & 12 & 口 蓋 & T3bN0M0 (II) & + & + & + & + & - & Ao \\
\hline
\end{tabular}

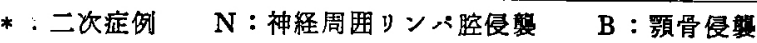




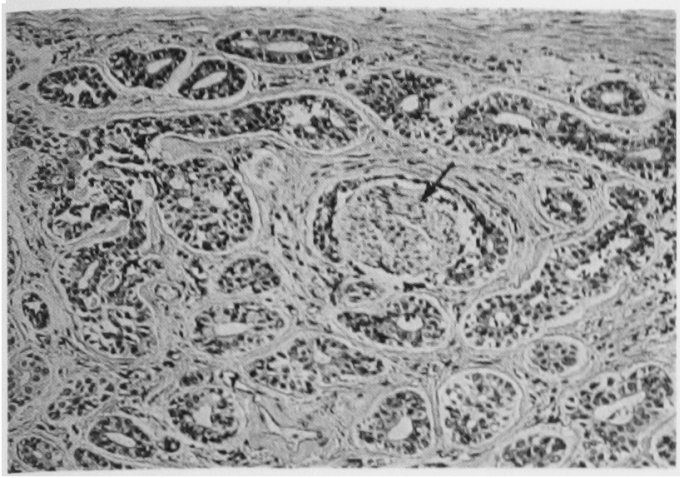

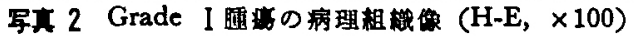

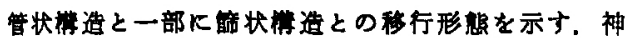
释線維周用への没（知印）

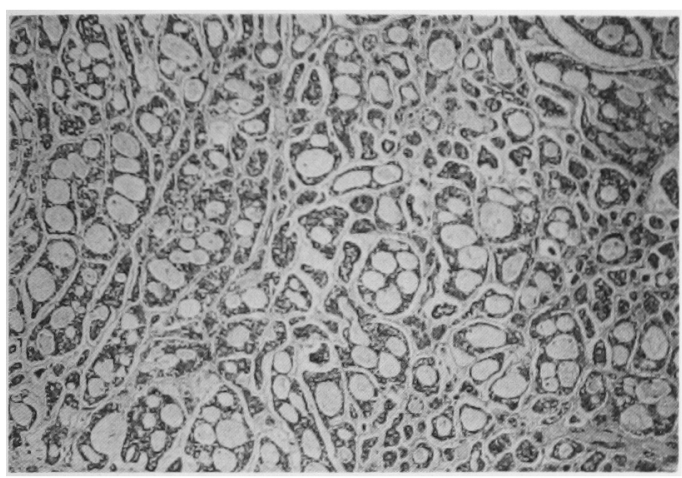

写真 3 Grade II 隀場の病理組像 (H-E, ×40) 定型的な節状構造の部分が大部分を占める

を含さ抎大全摘出術)であった。このらち初回腫煌摘出 後に追加手術を行ったるのが 4 例あり，また，患側皮席 合併切除（D-P 皮弁にて再建）が1例あった，頛部郭 清術は，迋隔転移例を除く $\mathbf{N}(+) 3$ 例に対し実施し， 全项部郭清行 2 例，上頸部郭清術 1 例であった。ささら K, 放射線療法（60 70 Gy，行後照射）併用が 2 例， 化学潦法併用が 3 例あり，いずれる再発時または行後腫 盼の牫存が認められた症例に実施した。

8）治療柽過（表 1，3）

全例の治療成績は，生存 7 例，原病死 5 例，他病死 1 例で，原病死 5 例中 4 例に遠隔転移（肺転移 3 例，脳転 移 1 例) を認めた。一次症例について組織型別にみる と, Grade I では 3 例中 2 例に局所再発または腫瘍の残 存を認めたが（写禹 5，6），とすに追加手術により良 好な経過を得た，4例とる生存し，遠隔転移はみられて いない. Grade IIの 3 例では原病死が 1 例あり, 初診時 顔面神経麻盘を伴い, 術後 3 年 8 か月て局所再発, 腷転 移なとにより死しした。一方，Grade IIIは最す経過不良

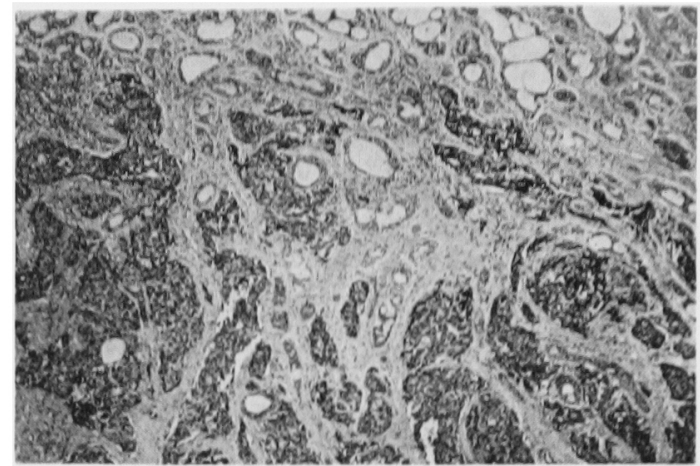

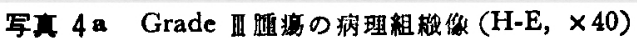

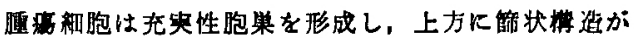
みられるが，充央型が偍位である，间買の線耯化が 比较的強い

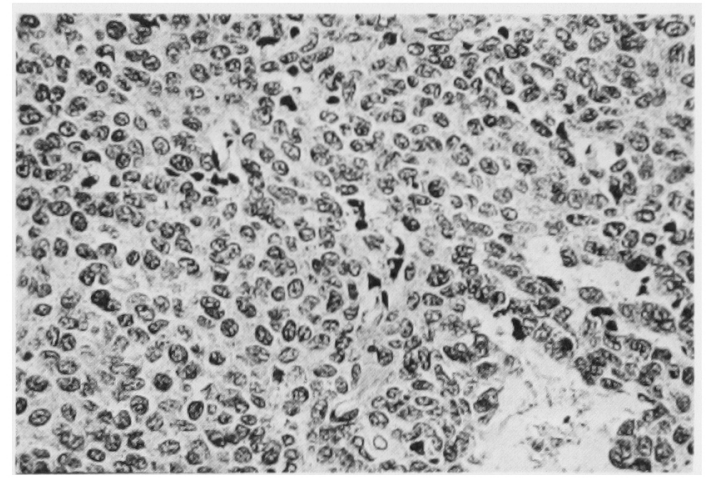

写茭 $4 \mathrm{~b}$ a の強抾大像 (H-E，×150) 中等度異型性を示し，核分裂像教見される

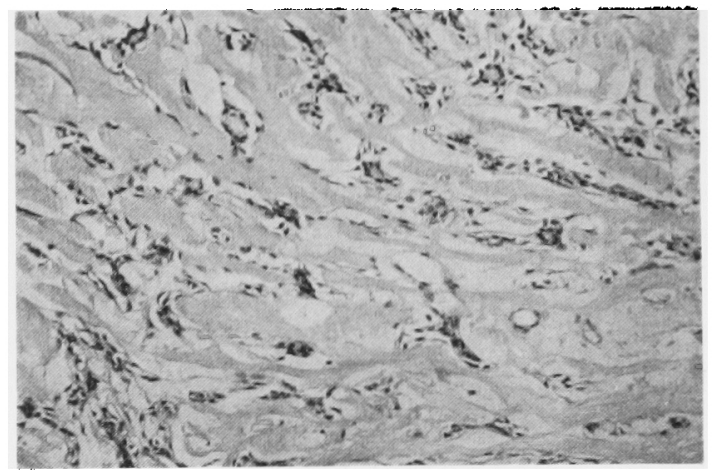

写真 4c a の他部位の病理組樴像 (H-E, × 100)

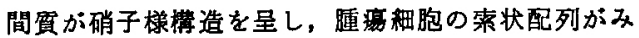
られる

であり，3 例中 2 例が死亡，とるに盿転移を生じ，ちち 1 例は来院時手街不能と診断された. 他のI例も切除断 端 (十) 例で, 術後 1 年 6 か月後に再発を認め(写直 7 ), 


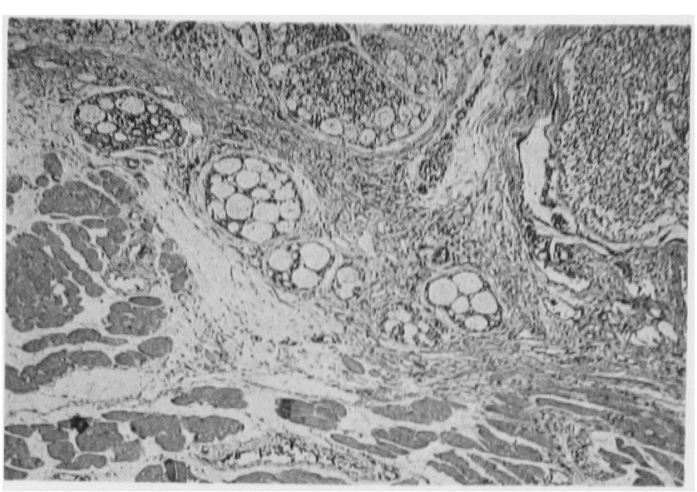

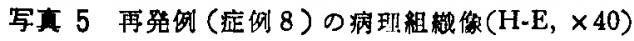

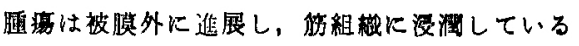

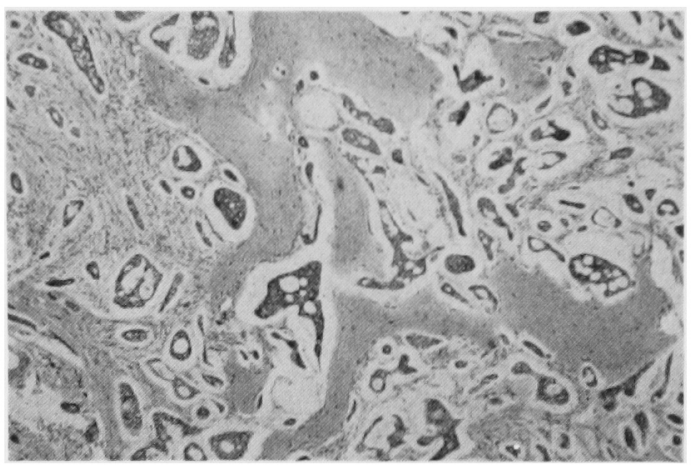

写真 6 再発例 (症例10)の病理租絨像 $(\mathrm{H}-\mathrm{E}, \times 40)$ 䫓骨への浸潤像を示す

追加手術を実施し現在経過観察中である。二次症例につ いては，Grade I 2 例が他病死 1 例, 生存 1 例であり, 再発，転移はみられなかった，Grade II 2 例はすへてて癌 死しているが，5ち1 例は肺転移による手術不能症例で あった。

$$
\text { 考察 }
$$

腺様襄胞癌は, 源腺, 副鼻腔, 咽頭、気管、乳腺など にも発生するか，唾液腺に好発し，特に䫁下腺，口蓋に 多くみられる，また，舌，口底，煩粘膜，口唇など口蓋 を除く小唾液腺や舌下腺においても，実数は少ないもの の普通にみられることから，口腔外科臨床に就いて比較 的遭遇することの多い喠液腺腫韵と思われる。従来から 本腫瘍に関する多くの臨床病理学的研究がなされ，報告 されているて11．それらを総括すると，経過は一般に長 く，しばしば局所再発，遠隔転移をきたす悪性度の高い 腫韵とされ，特に充害性の胞巣をなす非定型例ほど不良 な経過をとりやすいといわれている。

本腫瘍の病理組織型についていくつかの分類が提示さ

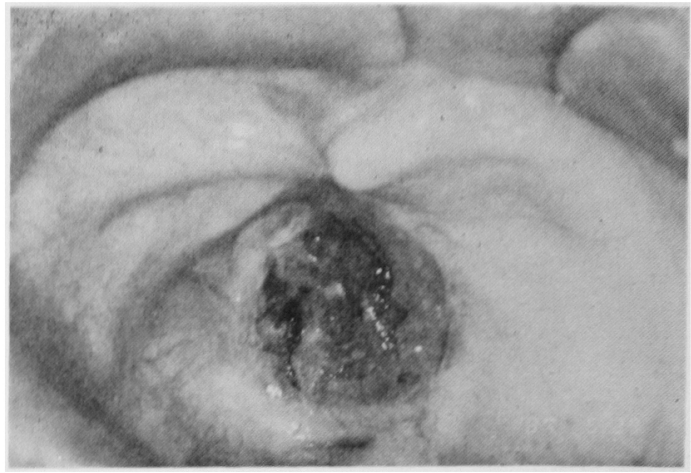

写真 7 a再発時口胵内（定何12）

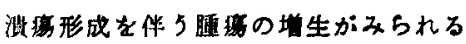

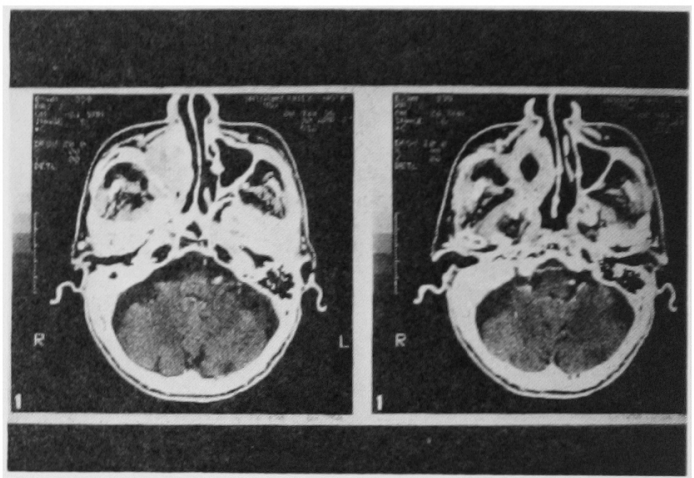

写槙 7 b a のCT 像

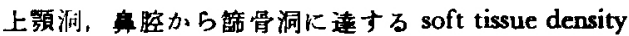
mass を兂める

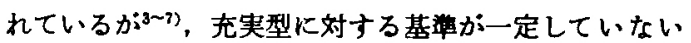
ため，必すしも予後との関連が明確に示されていなかっ たものもある。 この中で, Szanto 53), Perzin 54は, 30\%を指標として充実性胞巣の割合を決定し，累積生存 率との間に有意の差がみられたと述べた。われわれす本 分類を適用し，Gradeごとに臨床所見，治療释過を比较

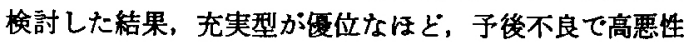
型である傾向が示唆された。 また，この㑯向は管状構造 を示し充実型を全く含まないGrade I と，充実型を含 む Grade II， IIIとで比較するとより顥著であった。

唾液腺癌の臨床病期分類については，今まで確立され たものがなく、主として耳下腺隀湯を対象とした AJC 案（1977）が試用されていた，今回の UICC の改訂党で 初めて唾液腺癌の TNM, Stage 分類が記載されたが, 特に大・小唾夜腺に関する区別は含まれていない，両者 を同一の基準で平価するのは，腫瑒の性状，臨床病態侸 差があり困難な点るあるが，岡部ら ${ }^{12}$ る述べているよう に共通の分類ができたことは，意義あるものと考えられ る，唾液腺癌の分類に执いて特票的といえるのは， $\mathrm{T}$ 分 
類において局所進展に関する細分類を設けたことであ る. 自験例では，顎骨への浸潤を認めたことによる $\mathrm{Tb}$ 例が多くみられたが，実際の分類に当たっては，唾液腺 の被膜外への進展の診断が難しく，特に小唾液腺に拉い ては部位の特性を考虑する必要があろう。症例数がそれ ほど多くない唾液腺癌の場合, 今回の分類はやや煩雑す ぎる印象も受けるが，今後多施設で本分類が検討され， 小唾液腺腫痬に拈いても一定の評価が得られることを期 待したい.

13例の臨床病期 (Stage) と組織型 (Grade) との関連 珄をみると，両者はほぼ相関し，進展例ほど経過は不良 であった，特に Stage IV では 4 例中 3 例（遠隔転移 2 例, 頸部リンパ節転移 1 例) 死亡し, 組織学的にも Grade IIIであった 2 例はともに肺転移を生じていた。ささらに， 予後に及ぼす影響として原病死 5 例の経過不良となった 要因を分析すると, これらは二次症例, 切除断端 (十) 例，顎骨への浸潤例であった。すなわち，一次治療，特 に䫇骨を含めた原発巣の完全切除の成否が予後に大きな 影響を与えると考えられ，これらの要因により手術が可 能であっても，腫瘍を十分制御しえない結果になるもの と思われた。 また，組織学的検索の中でリンパ管，血管 侵襲や細胞異型，核分裂像などが予後との関連上重要な 因子であると指摘している報告9 11) もあるが，今後さら に症例を重ねながら検討していきたい.

治療法は一般に本腫瘍の放射線感受性の問題などか ら,外科的切除が第一選択とされてきた。しかしながら， 実際には微視的な腫湯の残存は少なくなく，特に小唾液 腺腫瘍においては, 解剖学的特性から切除範团が制限さ れることもありらる。自験例において手術を行った顎下 腺 6 例, 口蓋 4 例を比較すると, 切除断端 (+) 例は顎 下腺，口蓋ともに 3 例で，口蓋の方が完全切除が困難と なりやすい傾向を示している.さらに, 切除断端 (十) 例はいずれも局所再発を生じており，追加手術など行っ たが，半数は腫瘍を制御できなかった。 また，下顎骨 に進展した症例では半側切除を含む区域切除を全例に実 施したが，広範払大手術にもかかわらず $3 / 5$ 例は死亡し た. 堀内ら ${ }^{13)}$ は, 腺様襄胞癌の多くは経過が長く, 遠隔 転移を有しながらも，長期間の社会生活が可能なので, 形態，機能の点から放射線治療の有用性を述べている. また，術後の残存腫瘍の程度に依存するが計画的な術後 照射を施行したり，発生部位によっては小線源治療，腔 内照射など放射線治療が主体となるなど，個々の症例に 応じた個別化された対応性を強調している ${ }^{13,14)}$ 。 いずれ にしても本腫瘍に対しては，十分な外科的切除のもと， 微視的残存腫瘍に対し追加あるいは予防照射として 50〜60 Gy の比較的高線量を適用するのが効果的と考え られる. 化学療法については, 進行例や二次治療例, 遠 隔転移例などで手術，放射線が適応されない場合に実施 されるのが多いようである ${ }^{15)}$. 近年，根治手術あるいは
根治照射後の adjuvant chemotherapy, immunochemotherapy がさかんに行われてきている，今後，腺様震胞 癌についても, 放射線と化学療法との併用, adjuvant immunochemotherapy，集学的治療 ${ }^{16)}$ な゙検討すべき課 題と思われる.

本腫瘍は前述したように発育が緩慢で経過期間が長 く，日常の臨床において早期発見や良性腫瘍との鑑別に 苦慮することが少なくない, 最近, 唾液腺造影, CT scan，RI scintigraphy，超音波検査などの画像診断学の 発展に伴い, Warthin 腫瘍など一部の腫瘍においてはか なりの質的診断も可能となってきた ${ }^{17)}$. しかし，実際に はこれらをすべて行っても，最終的には組織学的検査に たよらざるをえない，一般に唾液腺腫瘍に打いては，被 膜の損傷，瘦孔発生の問題や，同一腫瘍でも部位により 組織が異なりらるなどの特性から，生検は行われ難いの が実状である。 また，穿刺吸引細胞診に扣いても，同様 の理由から診断上の限界を否定できない，自験例では， 術前，潰瘍形成を伴う口蓋原発例や，顎下腺原発で口腔 粘膜に進展した症例では，生検を実施し確定診断を得た が，2 例においては良性腫瘍の臨床診断のもと手術を行 い, 切除標本にて腺様囊胞癌と診断された。 このよらな 切除後本腫瘍と診断された症例は，ほかにも報告されて おり ${ }^{18)}$, 臨床所見より良性腫瘍が疑われても本腫瘍の存 在を念頭におき，術中迅速診断などを必要に応じて行う べきであろう。また，口蓋原発で潜在性に進行した例 ${ }^{19)}$ や，肺転移を機会に顎下腺原発腫瘍が発見された例 ${ }^{20)}$ ど，特異な経過をたどるものもあり，十分な注意と観察 が必要である。

本腫瘍に特有な所見として，神経周囲組織への浸潤と 関連した神経症状の併発があげられる。自験例でも疼痛 を伴うものが比較的多く, 顔面神経麻㽻, 神経痛様疼痛 もみられた。 三叉神経痛を初発症状として，確定診断が 得られるまで 4 年を要した例 ${ }^{21)}$ 報告されている。この ほか経過については20年後に再発した症例 ${ }^{22}$ もあり，本 腫瘍の特性から長期的観点に立脚した経過観察が必要と いえる。

\section{結語}

唾液腺に原発した腺様囊胞癌13例（一次症例 9 例, 二 次症例 4 例) について, 臨床的ならびに病理組織学的に 検討を行い, 以下の結果を得た。

1）男性 7 例，女性 6 例で，中高年龄層（平均60歳） に多く発症した。

2) 原発部位は, 大唾液腺 8 例（顎下腺 7 例，耳下腺 1 例), 小唾液腺 5 例（口蓋 4 例, 煩部 1 例）であった.

3）初発および初診時症状として疼痛を併発した症例 が 8 例と多く, 受診までの期間は最高 17 年 (平均 6 年) と長期であった。 


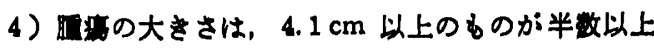
を占め，最大は耳下腺例の $7.0 \times 6.0 \times 2.0 \mathrm{~cm}$ であった，

5) 㯺床病期分類 (UICC, 1987) は, Stage I 1 例,

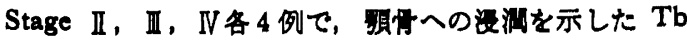
例が10例を占めた。

6) 病理組穖型分類 (Szanto 5， 1984) は, Grade I，II 各 5 例, Grade III 3 例であった。

7）治瘄法は外科窥法が主体で11例反手行を施行し,

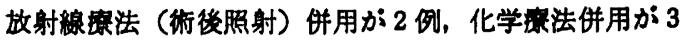
例あった。

8）治成统は，生存 7 例，病原死 5 例，他病死 1 例 であった，経過钼宗中に局所再発を照めたすのは6 例 で，再発亡での期間は很後平均 2 年 7 かであった。速 隔枟移は原病死 5 例中 4 例にみられた。

9) 組織学的 Grade の進行に伴い，充実型が传位な ほど予後不良で高要性型の所見を示した。

10）治㞠に関しては願用を含めた原発栄の完全切除が

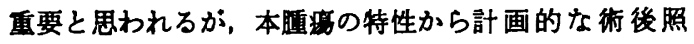
射, adjuvant immunochemotherapy をす含めた治濝法 か今後の検討課題と考えられた。

本論文の要旨は第 32 回日本口腔外科学会総会 (1987 年, 東京) とおいて発表した。

\section{引用 文 献}

1）石川杬朗監修: 啌病理学 II. 改行版, 永末卷 店, 京都, 1982, 749-753頁.

2) Hermanek, P. and Sobin, L.H.: TNM Classification of Malignant tumors. 4 th Ed, UICC, Geneva, 1987, p 30-32.

3) Szanto, P.A., Luna, M.A., et al.: Histologic grading of adenoid cystic carcinoma of the salivary glands. Cancer 54: 1062-1069 1984.

4) Perzin, K.H., Gullane, P., et al.: Adenoid cystic carcinomas arising in salivary glands. A correlation of histologic features and clinical course. Cancer 42: 265-282 1978.

5）高城 功：唾夜腺原発腺様晎胞癌についての病 理学的检討. 口病詰 43: 64-86 1976.

6) Marsh, W.I. and Allen, M.S.: Adenoid cystic carcinoma. Biologic behavior in 38 patients.
Cancer 43: 1463-1473 1979.

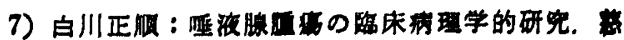
医眝 95: 1402-1419 1980.

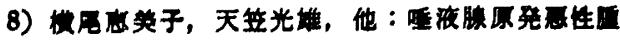

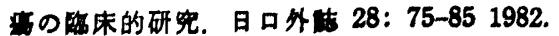

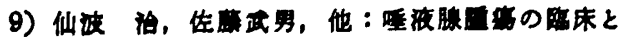

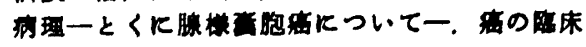
29: 287-291 1983.

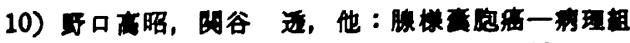

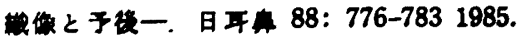

11) Morinaga, S., Nakajima, T., et al.: Histologic factors influencing prognowis of adenoid cystic carcinoma of the head and neck. Jpn J Clin Oncol 16: 29-40 1986.

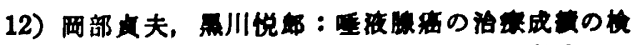
时一新しいTNM分用にしたがって一(如). 口 科詰 36: 1112-1113 1987.

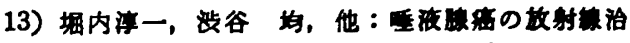

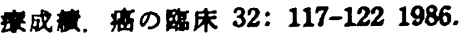

14) Simpson, J.R., Thawley, S.E., et al.: Adenoid cystic salivary gland carcinoma. Treatment with irradiation and surgery. Radiology 151: 509-512 1984.

15）犬山证夫, 场内正敏, 他 : 頭项部 adenoid cystic

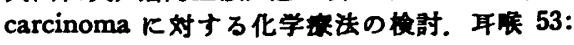
45-52 1981.

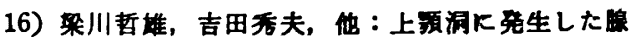

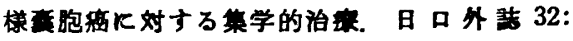
1516-1521 1986.

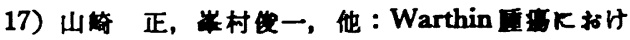
万画像訅断。只科誌 37: 36-46 1988.

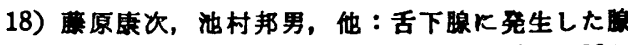

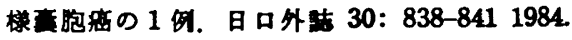

19）闪川一素，正木日立，他：口营下発生し，主と

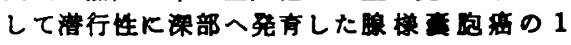
侧. 日外誌 32: 504-509 1986.

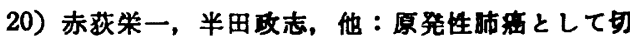

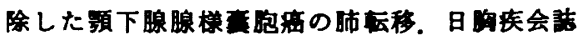
20: 701-704 1982.

21）村上通啮，浜川裕之，他：三叉神跬有を伴った

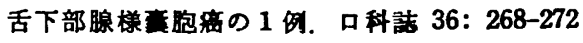
1987.

22）斉藤 弘, 田川夋郎、他：20年後に再発をきた したと思われる腺样篗胞盘の 1 症何. 日外誌 32: 411-417 1986. 